\title{
Trends in the global regulation of new breeding techniques and perspective
}

\author{
Donghern $\mathrm{Kim}^{1} \cdot$ Seung-Man $\mathrm{Suh}^{2} \cdot \mathrm{Ji}$-Yeong Kim${ }^{2} \cdot$ Hae-Yeong Kim ${ }^{2}$
}

\section{신육종기술의 규제 전망 및 문제점}

\author{
김동헌 ${ }^{1} \cdot$ 서숭만 ${ }^{2}$ 김지영 ${ }^{2}$ 김해영 2
}

Received: 12 November 2018 / Accepted: 18 November 2018 / Published Online: 31 December 2018

(C) The Korean Society for Applied Biological Chemistry 2018

\begin{abstract}
New Breeding Techniques (NBTs)' have been one of hot issues, since their future will be affected profoundly by national as well as international regulatory landscapes. In this review, we compare characteristics of NBTs with conventional and genetic modification, and analyze genetically modified organism (GMO) regulatory systems in the context of possible regulation of NBTs. NBTs are very heterogeneous in terms of principles, methodologies, and final products. As Living Modified Organisms (LMO) is defined in the Cartagena Protocol on Biosafety (CPB) as an organism containing novel combination of genetic materials obtained by the use of modern biotechnology, $\mathrm{CPB}$ as well as other national legislations locate itself somewhere in the middle between product-based and process-based regulations. It is also noted that jurisdictions with regulatory systems more oriented to product-based one tend to be more productive and decide or may decide to exempt site-directed nucleases-1 from GMO regulation. In this context, Korean legislations are reviewed to clarify the commons and differences in GMO definitions. Act on Transboundary Movement of LMO Act, Food Sanitation Act and Agricultural and Fishery Products Quality Control Act are three major acts to regulate GMOs. It is noted that there are
\end{abstract}

Hae-Yeong $\operatorname{Kim}(\bowtie)$

E-mail:hykim@khu.ac.kr

${ }^{1}$ Green Bio Consulting, 145 Dongsuwon-Ro, Suwon, Republic of Korea

${ }^{2}$ Institute of Life Sciences and Resources, Department of Food Science \& Biotechnology, Kyung Hee University, Republic of Korea

This is an Open Access article distributed under the terms of the Creative Commons Attribution Non-Commercial License (http://creativecommons. org/licenses/by-nc/3.0/) which permits unrestricted non-commercial use, distribution, and reproduction in any medium, provided the original work is properly cited. differences in the definition of LMO or GM food/products especially between the LMO Act and the Food Sanitation Act. Such differences may cause conflicts between Acts when policydecision regarding the regulation of NBTs is made. Therefore, it is necessary to reorganize legislations before policies regarding the regulation of any techniques from biotechnology are made.

Keywords Breeding $\cdot$ EU Court of Justice $\cdot$ Gene editing $\cdot$ New Breeding Techniques $\cdot$ Regulation

\section{서 론}

유전자변형(GM, genetic modification)은 전통육종(conventional breeding)을 이용한 농작물 신품종 육성의 여러 가지 기술적 문 제를 해결할 수 있는 유력한 수단으로서 1990년대 중반 이후 그 상업적 활용이 지속적으로 증가하고 있다[1]. 그러나 환경단 체 등의 반대 캠페인에서 비롯된 사회적 논란과 국가, 지역 및 세계 수준의 복잡한 규제 체계, 그리고 이에 따른 천문학적인 제품 개발 비용 등으로 인해 이 기술의 잠재력이 크게 훼손됐 다는 점도 부인하기는 어렵다[2]. 한편 생명과학 분야의 눈부신 발전에 힘입어 유전자변형 혹은 전통육종으로 분류하기 어려운 다수의 “신육종기술”(NBTs, new breeding techniques)이 출현했 다. 2007년 EU 회원국들의 요청에 의해 유럽연합 집행부가 설 치한 작업반에서 발굴한 site-directed nucleases $(\mathrm{SDN})$ 를 이용 한 유전자 교정(gene 혹은 genome editing), oligonucleotidedirected mutagenesis (ODM), cisgenesis와 intragenesis, 역육종 (reverse breeding), 아그로 접종(agro-infiltration), 접목(grafting), RNA-dependent DNA methylation (RdDM) 등은 이 후 다수 의 규제 관련 보고서에서 공통적으로 다룬 신육종 핵심기술이 라고 할 수 있다[3-9]. 
신육종기술의 개발이 진전되어 일부 기술의 실용적 활용이 현 실화됨에 따라 관련 기술과 제품이 유전자변형 생물체(GMO, genetically modified organism)의 한 부류로서 규제될 것인지가 초미의 관심사로 떠오르고 있다[10-11]. 특히, 유전자변형 생물 체가 지나치게 엄격하게 규제되고 있다고 생각하는 관련 과학 자와 산업체 관계자들은 신육종기술과 그 제품이 $\mathrm{GMO}$ 와 같은 운명에 처하게 될 수도 있다는 것에 대해 심각하게 우려하고 있다[11-12]. 반면, 유기농업 관련자들은 신육종기술에 대해서도 $\mathrm{GMO}$ 와 마찬가지로 반대의 입장을 표명하고 있다[13].

신육종기술 중 규제 여부에 대한 관심이 가장 큰 것은 유전 자 교정이라고 할 수 있다. 유전자 교정은 zinc-finger nuclease (ZFN), transcription activator-like effector nuclease (TALEN), clustered regularly interspaced short palindromic repeats/ CRISPR associated (CRISPR/Cas9) 등을 이용하여 목표 생물체 내의 유전체 특정 위치를 특이적으로 절단한 후 생물체 자체의 DNA 복구과정에서 변이 발생을 유도하는 기술이다[3-8]. 2018 년 4월 미국 농무부(USDA)는 유전자 교정 산물을 $\mathrm{GMO}$ 규제 대상으로 삼지 않을 것이라는 입장을 표명하였다[14]. 반면에, 2018년 7월 유럽사법재판소는 전통적 방법이 아닌 새로운 변이 창출 기술로 개발한 생물은 $\mathrm{GMO}$ 규제 대상에 포함된다고 판 결하였고 유럽연합 집행부가 이에 따른 적절한 규제체계를 마 련할 것을 주문하였다[15,16]. 이처럼 서로 상반되는 결정은 양 국 $\mathrm{GMO}$ 규정의 차이로 인한 것이다. 이로 인해 유전자 교정, 더 나아가서는 신육종기술에 대한 규제가 앞으로 어떻게 진행 될 것인지 예측하기가 더 어려워졌다고 할 수 있다[17].

국내에서도 신육종기술, 특히 유전자교정 산물의 규제 가능 성에 대해 높은 관심과 우려를 표하고 있다[12,18]. 이들을 $\mathrm{GMO}$ 에 포함시킬 경우 상당한 경쟁력을 갖고 있으면서도 막대 한 규제 비용과 시간의 소요로 실용화 확산에 어려움을 겪고 있는 유전자변형 기술의 전철을 밟을 것이라고 걱정하는 것이 다. 따라서 본 보고에서는 신육종기술의 개요와 유전자 교정을 중심으로 한 각 국의 규제 전망 그리고 국내 유전자변형 생물 체 규제 규범을 비교, 검토하여 향후 신육종기술 규제 정책 수 립을 위한 참고자료를 제공하고자 하였다.

\section{신육종기술의 개요}

\section{유전자교정}

변이창출은 품종 개발의 핵심 요소 중 하나라고 할 수 있지만 자연 혹은 유도(방사능, 화학물질 처리) 돌연변이는 발생 확률 이 매우 낮고, 무작위적으로 발생하기 때문에 그 활용이 제한 적이다. 유전체 염기서열 분석 기술과 생명과학의 발달에 힘입 어 개발된 유전자교정은 기존 기술에 비해 변이 창출의 정확도 와 효율성을 크게 향상시켰다. 이 기술의 핵심은 ZFN, TALEN 과 CRISPR/Cas9 등의 위치특이적 핵산분해효소(SDN) 시스템 을 이용하여 유전체의 특정부위를 선택적으로 절단(DSBs; double strand breaks)하는 것이다. 이후에는 생물체 고유의 기 작에 의해 절단부위의 복구가 일어나며, 이 과정에서 염기 중 일부가 소실되거나(deletion), 단편이 삽입되거나(insertion) 혹은 다른 염기로 치환(substitution)되어 변이를 일으킨다[7].

$\mathrm{ZFN}$ 을 이용한 유전자 교정 기술은 1996년 미국 존스홉킨스
대학의 Chandrasegaran 박사연구팀이 cys2-his2 zinc-finger 도 메인에 Fok1 nuclease 도메인을 결합하여 DNA의 특정 염기서 열 부위를 절단하는 새로운 제한효소를 제작한 것에서부터 시 작되었다[19,20]. 30 개의 아미노산이 $\beta \beta \alpha$ 구조를 이루는 zincfinger 모듈 하나는 triplet nucleotide 하나와 선택적으로 결합한 다. A, T, G, C 4개의 염기로 만들 수 있는 64개의 triplet 전 체에 대응할 수 있는 ZF 모듈은 아미노산 서열을 조금씩 바꾼 combinatorial library 선발이나 구조 디자인을 통해 확보되었다. 대부분의 생물체는 DNA 내 18-24 nucleotide sequence의 독특 한 서열을 갖고 있다. 이를 인식하는 데에는 6-8개의 $\mathrm{ZF}$ module이 필요하며, dimer로 작용하는 $\mathrm{ZFN}$ 의 특성상 $\mathrm{ZF}$ 도메 인 당 3-4개의 ZF module을 구성하면 대상 생물체 DNA 염기 서열 특이적으로 작동할 수 있다[20-23].

Pseudomonas속 박테리아에서 발견된 transcription activatorlike effector (TAL effector)에는 각각이 33-35 아미노산으로 이 뤄진 10-30개의 tandem repeat로 구성된 DNA 결합도메인이 있 다. 각 repeat는 DNA 염기 하나를 인식하는데, 염기 특이성에 는 repeat 내의 12,13 번에 위치한 아미노산으로 구성된 repeat variable diresidue가 관여한다[21-24]. 즉 Asn-Ile는 A, Asn-Gly 는 $\mathrm{T}, \mathrm{His}-\mathrm{Asp}$ 는 $\mathrm{C}$ 를 인식하고 Asn-Asn은 $\mathrm{G}$ 와 $\mathrm{A}$ 를 인식하는 데, 이 경우 $\mathrm{A}$ 보다는 $\mathrm{G}$ 에 대한 specificity가 더 높다. 또한 $\mathrm{TAL}$ effector와 결합하는 target DNA sequence의 5'은 항상 thymidine이라는 특성이 있다. TALEN은 TALE의 DNA 결합 도메인에 FokI nuclease 도메인을 결합하여 만든 $\mathrm{SDN}$ 으로서 $\mathrm{ZFN}$ 에 비해 설계와 제작이 쉽다는 장점이 있다. 또한 repeat의 숫자를 늘림으로써(repeat extension) 길이가 더 긴 DNA와 선 택적으로 결합하는 것이 가능하여 타겟 site 선정에 있어서의 제한이 적다. 그러나 $\mathrm{ZFN}$ 에 비해 단백질 크기가 커서 packaging과 delivery가 어려울 수 있다는 단점이 있다.

CRISPR/Cas9은 RNA-guided DNA cleavage라는 박테리아의 면역체계를 유전자 교정에 활용한 시스템이다[22-24]. 박테리아 는 외래 DNA로부터 protospacers를 수집해서 자신의 유전체 내 에 삽입시킨 후, 짧은 guide RNA를 발현시켜 protospacer와 서 열이 맞는 모든 $\mathrm{DNA}$ 를 파괴시킴으로써 외부의 침입으로부터 자신을 보호한다. 박테리아 Streptococcus pyogenes가 가진 CRISPR/Cas type II-A에는 CRISPR RNA (crRNA), transactivating crRNA (tracrRNA), Cas9 protein 등 3개의 유전자 가 coding되어있다[22,25]. 박테리아 유전체의 CRISPR loci에 삽입된 외래 DNA 단편(spacer)의 전사와 process에 의해 CRISPR RNA (crRNA)가 생산된다. 이 후 crRNA annealing에 의해 transactivating crRNA (tracrRNA)가 만들어지며 tracrRNA-Cas9이 $\mathrm{crRNA}$ 와 매칭되는 서열의 외래 DNA를 절단한다. Cas9의 타 겟 인식에는 crRNA의 seed sequence와 crRNA 결합 부위 위 쪽에 보존된 2 개의 nucleotide를 포함하는 protospacer adjacent motif가 필요하다. 유전자교정의 효율성을 제고하기 위해 개발 된 simplified version은 Cas9과 단일 guide RNA로 구성된다. tracrRNA와 short, mature crRNA를 결합한 형태인 guide $\mathrm{RNA}$ 는 타겟 부위를 인식하고 결합하는 역할을 담당한다. ZFN, TALEN과 달리 CRISPR/Cas9은 유전자교정 타겟에 따라 결합 도메인을 디자인할 필요 없이 guide RNA 중 $20 \mathrm{bp}$ 만 재설계하 면 된다. 따라서 다양한 타겟에 대한 적용성이 우수하고 효율 이 높으며 다중 guide RNA를 사용할 경우 한 번에 다수의 타 
겟을 교정할 수 있다는 장점이 있다[23].

유전자교정에서의 변이는 $\mathrm{SDN}$ 에 의해 절단된 타겟 $\mathrm{DNA}$ 의 복구 과정 중에 발생한다[26]. 동식물 등 진핵세포의 일반적인 복구 과정인 '비상동말단연결'(Non-homologous end joining)은 repair template 없이 절단된 DNA 사슬을 연결하는 것으로, 이 과정에서 무작위적으로 변이가 발생할 수 있으며 이러한 변이 를 $\mathrm{SDN}-1$ 로 분류한다. 복구에 repair template가 필요한 '상동 유도수선'(Homology-directed repair)은 절단부위와 염기서열 상 동성을 갖지만, 일부 서열을 변경시킨 repair (혹은 donor) $\mathrm{DNA}$ 를 의도적 변이 창출의 가이드로 이용한다. Repair DNA 를 어떻게 제작하느냐에 따라 변이 산물을 SDN-2 (SDN-1 변 이체와 동일하거나 유사)와 SDN-3 (Repair DNA에 수 $\mathrm{kb}$ 에 달하는 단편을 삽입하여 새로운 유전자를 도입)로 구분할 수 있다.

유전자교정 기술의 개발이 활발해짐에 따라 이를 활용한 제 품의 개발도 점차 늘어나고 있다. 미국 USDA에서 수행하고 있 는 유전자변형 생물체 규제 시스템의 하나인 'Am I regulated' 프로그램에 따르면, 2015년 이후 2018년 10월까지 규제대상여 부에 대한 문의가 진행된 유전자교정 산물의 숫자는 26건에 달 한다[27]. 이 중 Calyxt사에서 개발한 저온저장성 개선 감자[28], 오일성분 개선 콩[29]은 TALEN 기술이 적용된 예이며, Corteva사에서 waxy1 유전자를 knock-out시킨 옥수수에는 CRISPR기술이 적용되었다[30]. 이외에도 갈변저항 버섯[31], Powdery mildew 병 저항성 밀[32], 제초제 저항성 담배[33] 등 도 각각 CRISPR, TALEN, ZFN 등의 유전자교정 기술을 적용 하여 육성한 제품이다.

우리나라도 상당한 유전자교정 기술 경쟁력을 갖추고 있다 [18]. 기초과학연구원의 김진수박사 연구팀은 상당수의 관련 원 천 기술 특허를 확보하고 있으며 툴젠 등의 기업과 경상대, 경 희대, 서울대, 전남대, 포항공대 등의 대학에서 다양한 기초응 용연구를 수행하고 있다. 한편 농촌진흥청에서는 기술의 농업적 활용을 위해 신육종기술 연구프로그램을 기획하는 등 이 분야 의 경쟁력과 기술 확보를 위해 노력하고 있다.

\section{ODM}

$\mathrm{ODM}$ 에서는 유전자 교정과 달리 $\mathrm{SDN}$ 을 이용하지 않고 20-100 nt 정도의 oligonucleotide를 이용해 변이를 유도한다[5,7-8,34]. Oligonucleotide는 바꿀 염기를 제외하고는 타겟 시퀀스와 동일 하게 합성한다. 이를 대상 생물체의 세포에 넣으면 타겟 부위 에 결합하며, 이때 발생하는 mismatch를 세포의 DNA 수선체 가 제거한다. 이 과정에서 도입된 oligonucleotide가 template로 사용될 경우 1 개 혹은 여러 염기의 치환, short deletion 또는 insertion과 기존 변이의 reversal 등 의도한 변이가 발생하며 template로 이용된 oligonucleotide는 분해된다. ODM에서는 DNA 절단 없이 oligonucleotide를 이용하여 게놈상의 원하는 위 치에 자연적인 allelic 변이를 유도하므로 변이체 획득 효율이 최대 $0.05 \%$ 로 낮은 편이다. 또한 DNA나 RNA 형태의 oligonucleotide를 식물 세포의 원형질체에 넣어야 하므로 원형 질체 배양과 식물체 재분화 체계가 확립된 대상으로 활용범위 가 제한된다. 다만 $\mathrm{ODM}$ 은 방사능 또는 화학물질 처리와 같은 전통 변이 창출 기술에 비해 변이의 무작위성을 제거할 수 있 다는 장점이 있다. 캐나다에서는 $\mathrm{ODM}$ 으로 제초제 저항성 유 채를 개발하여 상업화를 위한 CFIA와 Health Canada 승인을
받은 바 있다[34].

\section{Cisgenesis와 intragenesis}

Cisgenesis와 intragenesis의 기본 원리는 유전자변형 생물체를 생산하는 transgenesis와 동일하다[7-9,35]. 다만 transgenesis에 이용하는 유전자는 동식물, 미생물 등 그 유래에 제한을 두지 않는 것에 반하여 cis(intra)genesis에서는 대상 생물종 혹은 교 배가 가능한 근연종 유래의 유전자를 이용한다. Cisgenesis와 intragenesis는 도입유전자의 구조에 차이가 있다. Cisgenesis에 서는 내재 유전자 세트를 가공하지 않고 본래 가지고 있던 promoter, 조절부위, intron과 exon을 그대로 형질전환에 이용한 다. 반면에 intragenesis에서는 서로 이질적인 유전자와 promoter 등을 결합시키거나 intron이 제거된 mature cDNA 유전자로 만 들어 이용한다. 내재서열을 이용한 RNAi 기술도 intragenesis로 분류된다. Cisgenesis에서는 도입유전자가 본래의 조절 기작에 따라 발현되므로 발현 강도 정도에만 변화를 일으키지만, intragenesis에서는 유전자 발현 정도, 발현 패턴의 조절도 가능 하다. 이런 측면에서 볼 때 cisgenesis가 intragenesis보다 더 자 연적인 것에 가깝다고 할 수 있다.

Cisgenesis와 intragenesis로 형질전환체를 만들 때 고려해야 할 또 다른 요소는 형질전환 과정 중 식물체로 이전되는 agrobacterium의 T-DNA와 기타 외래 DNA단편이다. 식물에도 Plant transfer DNA라는 T-DNA와 유사한 성질을 가진 DNA 시퀀스가 존재하며, 이를 형질전환에 활용하면 T-DNA단편 삽 입의 문제를 해결할 수 있다. 이외에 vector backbone, 선발 마 커 등 형질전환체에서 발견할 수 있는 비식물 유래 DNA단편 을 형질전환 식물 유전체에서 배제하기 위해서 무선발 형질전 환, cotransformation, recombination site를 이용한 형질전환체 선발 후 마커 유전자 제거 등의 전략이 사용되기도 한다. Cisgenesis 나 intragenesis 기술을 활용하여 개발한 작물의 예로 역병 저항 성 감자(cisgenic)가 포장 시험 중이며[36], cisgenic 곰팡이병 저 항성 사과[37], intragenic 딸기[38] 등도 보고된 바 있다.

\section{역육종(Reverse Breeding)}

역육종은 우수 형질의 1대 잡종으로부터 부모세대의 inbred line 을 확보하여 잡종강세 종자를 지속적으로 생산하기 위한 전략 이다[3-8,39-41]. 잡종강세는 1대 잡종 작물이 부모세대보다 크 기와 성장, 생산 측면에서 우수한 형질을 보이는 현상을 말한 다. 그러나 이러한 잡종강세는 많은 조합의 시행착오적(trial and error) 교배를 통해서만 획득할 수 있고 어떤 부모계통을 교배 해서 잡종강세를 획득했는지 불분명할 때도 있다. 이 경우 후 대를 전개하면 생식생장기의 재조합으로 인해 유전자가 서로 뒤 섞여 잡종강세의 소실로 이어지게 된다. 이를 방지하기 위해 역 육종에서는 잡종식물의 유전자재조합을 억제하고 반수체 육성 과 double haploid 획득을 통해 잡종강세 후대 생산이 가능한 부모계통(inbred line)을 육성한다.

역육종에 적용되는 기술의 핵심은 생식생장기의 유전자 변이 혹은 meiotic crossover를 억제하는데 있다. 이를 위해서 RNAi 나 small interfering RNA (siRNA)에 의한 전사 후 유전자침묵 (Post-transcriptional gene silencing)으로 meiotic recombination에 필수적인 유전자의 발현을 억제한다. 애기장대의 $a s y 1$, 벼의 $a s y 1$ 유사유전자인 pair2 등과 $d m c 1, s d s, p t d, s p o 11$ 등 
crossover 관여 유전자가 유전자 침묵의 대상이 될 수 있다. Meiotic recombination 억제를 위해 이용된 PTGS나 dominant negative mutation에서는 형질전환 기술이 일시적으로 활용되지 만, 후대 육성과정에서 transgene이 제거된 null mutant 선발을 통해 transgene이 제거된 최종 산물이 확보된다[39-41].

\section{아그로 접종(agro-infiltration)}

아그로 접종은 외래 유전자를 타겟 식물 유전체에 영구적으로 도입하는 것이 아니라 식물체 내에서 일시적으로 발현시켜 도 입 유전자의 기능을 확인하거나 이용하는 기술이다. 예를 들어 바이러스 같은 식물 병원균 유전자를 agrobacteria의 plasmid에 넣은 후 식물 잎에 접종함으로써 식물의 병저항성 유전자 발현 을 유도, 동정하여 이 후의 작물 육종에 활용할 수 있다. 또한 인간 growth hormone과 같은 고가의 단백질 유전자를 식물체 에서 일시적으로 발현시켜 바이오 의약품 소재 생산에도 활용 할 수 있다. 아그로 접종에서는 외래 유전자가 host cell의 게놈 에 영구적으로 삽입되지 않고 일시적으로 발현되므로 유전체 염 기서열의 변화를 가져오지 않는다[3-8,42-43].

GM 대목 이용 접목(Grafting on Genetically Modified Rootstock) 접목은 원예와 임목에서 널리 이용되는 기술로, 작물의 접수 (scion)를 동종 혹은 유사한 종의 대목(rootstock)에 접목하여 대 목의 우수한 형질을 접수의 농산물 생산에 활용하는 것이다. 유 전자변형 작물을 대목으로, 일반 작물을 접수로 하여 접목하였 을 경우 접수에서 생산하는 생산물의 유전자 변형은 일어나지 않는다. 다만 대목과 접수를 연결하는 관다발 조직을 통해 물 질의 이동이 일어나는데 물, 당류 등 소분자뿐만 아니라 RNA, 단백질과 같은 거대 분자의 이동도 보고된 바 있다. 유전자변 형 대목이 생산한 RNA가 접수로 이동하여 접수의 유전자발현 에 영향을 미친다면, 이는 접수 식물을 형질전환하여 유전자변 형 작물을 만드는 것과 비교했을 때 접수의 유전체 염기서열에 변화가 없다는 것을 제외하면 동일한 효과를 보여준다[3-8,44].

\section{RNA-dependent DNA Methylation (RdDM)}

$\mathrm{RdDM}$ 은 타겟 유전자와 homology가 있는 double strand RNA (dsRNA)를 이용하여 유전자의 특정 염기에 메틸기를 부가함으 로써 발현을 조절하는 기술이다. 세포 내에 넣어준 dsRNA를 식물의 방어 기작이 인식하면 DICER 단백질이 dsRNA를 분해 하여 $24 \mathrm{nt}$ 의 siRNA로 만든다. 이렇게 만들어진 siRNA는 식 물 방어 기작을 자극하여 DNA methylation 과정을 일으키고, 타겟 사이트에 메틸화를 일으키게 된다. 이와 같은 방법으로 얻 은 형질의 변화는 유전자 염기서열의 변화가 없는 epigenetic modification이다. 다만 메틸화한 DNA 염기의 물리적 성질 변 화에 따른 염색체 구조 변화와 특정 유전자 발현의 변화가 몇 세대에 걸쳐 유지된다[3-8,45].

작물의 $\mathrm{RdDM}$ 유도는 $\mathrm{dsRNA}$ 를 생산하는 식물 바이러스를 이용(VIGS, virus induced gene silencing)하거나 dsRNA를 코 딩하는 유전자를 이용한 형질전환 등을 통해 이뤄질 수 있다. VIGS의 경우 dsRNA를 생산하는 virus 유래 sequence는 생식 생장 과정에서 없어지고 후대로 전이되지 않으며, 이를 이용한 형질전환체는 후대육성 중 선발을 통해 유전자 제거가 가능하 다. 따라서 $\mathrm{RdDM}$ 으로 생산된 식물체는 외부에서 넣어준 유전
자와 내재 DNA 염기서열의 변화가 없는 형질 변이가 가능하다.

\section{전통육종과 유전자변형 그리고 신육종기술의 비교}

전통육종과 유전자변형 그리고 신육종은 공통적으로 작물의 형 질을 개선하는데 활용되는 기술이다[7]. 그러나 자연 발생 혹은 유도 변이체를 선발하거나 교배를 통해 우수 형질이 도입된 품 종을 육성하는 전통육종과는 달리 $\mathrm{GM}$ 과 신육종기술은 '현대생 명공학'을 이용하여 유용한 신형질을 가진 우수 품종을 육성하 는 기술이라는 점에서 차이를 보인다. $\mathrm{GM}$ 에서는 유전자 분리, 재조합, 게놈 삽입 등을 통해 새롭게 도입된 유전자의 기능에 서 유래된 새로운 형질을 대상 생물체에 부여한다. 반면 신육 종은 적용 기술에 따라 다양한 방식으로 영구적이거나 일시적 인 작물 형질 변경이 가능하다. 이와 같이 전통육종과 $\mathrm{GM}$ 그 리고 신육종은 각각 유사성과 차별성을 가지고 있지만 각 기술 이 처한 규제 환경은 매우 다르다. 전통육종은 교배로부터 방 사능/화학물질 처리에 이르기까지 특별한 규제 없이 해당 기술 을 이용할 수 있지만, 유전자변형은 국내외적으로 매우 엄격하 고 복잡한 규제 대상이며 신육종기술의 규제와 관련된 각 국의 정책 결정은 아직까지 현재 진행형으로 향후 결정의 향방에 따 라 잠재력 구현 등 기술의 운명이 결정될 것으로 예상되지만 다양한 사회 및 환경적 요인 등 규제에 대한 불확실성이 단기 간 내에 해결되기는 어려울 것으로 전망된다[17].

현재 엄격한 규제 대상인 GMO, 규제 범위 밖에 있는 전통 육종과 신육종기술 사이의 유사점과 차이점은 신육종기술의 규 제 여부를 결정하는데 있어서 중요한 고려사항 중의 하나일 것 이다. 2017년 유럽연합의 High Level Group of Scientific Advisor SAM (Scientific Advice Mechanism) 보고서를 통해 변이 발생의 무작위성, 외래유전자의 존재, 검출과 동정 등의 측면에서 각 기술을 비교한 바 있다[7]. Table 1에서 정리한 바 와 같이 전통육종은 변이의 무작위성과 비의도적 변이 창출 가 능성이 매우 높다. 반면에 $\mathrm{GM}$ 기술의 경우 상대적으로 무작위 적 변이 발생 가능성은 낮으나 transgene의 삽입 위치 등으로 인한 비의도적 변이가 발생할 수 있다. 신육종기술의 경우 무 작위적 또는 비의도적 변이발생 가능성이 가장 낮다. SDN-1, 2 기술의 산물은 전통육종과 동일하지만 변이발생 위치는 정확히 조절될 수 있으며 $\mathrm{SDN}-3$ 의 경우 $\mathrm{GM}$ 기술과 같은 효과를 정 확한 위치에 발생시킬 수 있다. 그리고 cisgenesis와 intragenesis 의 비의도적 변이 발생가능성은 $\mathrm{GM}$ 기술과 동일하고, $\mathrm{ODM}$ 의 무작위 또는 비의도적 변이발생 가능성은 매우 낮다. 역육종은 중간에 형질전환단계가 포함되어 있지만 최종산물을 만드는 과 정에서 전통육종의 기술을 활용하여 도입유전자를 제거하며, 이 단계에서 전통육종과 같은 정도의 비의도적 변이가 발생할 가 능성이 있다. 아그로 접종, 접목, $\mathrm{RdDM}$ 은 대상 생물 유전체의 DNA 염기서열 변이를 유도하지 않으므로 변이 발생 가능성은 없다고 할 수 있다.

현대생명공학으로 새롭게 조합된 외래 $\mathrm{DNA}$ 의 존재와 관련 된 경우, 방사능 등 인위적 손상 복구과정에서의 변이나 교배 가능한 생물 종 간의 유전자 교환이 일어나는 전통 육종은 원 리 상 외래 $\mathrm{DNA}$ 를 이용하지 않는다. $\mathrm{GM}$ 기술의 경우에는 외 래 DNA가 존재하며, 신육종기술은 적용 기술에 따라 외래 
Table 1 Comparison of conventional breeding, genetic modification and new breeding techniques in terms of uncertainty, presence of foreign novel recombinant DNA, detection and identification. Reorganized from the description of reference [7]

\begin{tabular}{|c|c|c|c|c|c|c|}
\hline & & \multirow{2}{*}{$\begin{array}{c}\text { Randomness/ } \\
\text { Unintended genetic } \\
\text { change }\end{array}$} & \multicolumn{2}{|c|}{ Novel Recombinant DNA } & \multirow{2}{*}{ Detection } & \multirow{2}{*}{ Identification } \\
\hline & & & Intermediate Stage & Final Product & & \\
\hline & $\begin{array}{c}\text { Conventional } \\
\text { Breeding }\end{array}$ & High & N/A & N/A & Difficult & N/A \\
\hline & GM & Low & Yes & Yes & Easy & Possible \\
\hline \multirow{10}{*}{$\begin{array}{l}\text { New Breeding } \\
\text { Techniques }\end{array}$} & Gene Editing & & & & & \\
\hline & SDN-1 & Very Low & Yes/No & No & $\begin{array}{l}\text { Easy with } \\
\text { Information }\end{array}$ & Impossible \\
\hline & SDN-2 & Very Low & Yes/No & No & $\begin{array}{c}\text { Easy with } \\
\text { Information }\end{array}$ & Impossible \\
\hline & SDN-3 & Very Low & Yes & Yes & $\begin{array}{c}\text { Easy with } \\
\text { Information }\end{array}$ & Possible \\
\hline & ODM & Very Low & No & No & $\begin{array}{l}\text { Easy with } \\
\text { Information }\end{array}$ & Impossible \\
\hline & $\begin{array}{c}\text { Cisgeneis/ } \\
\text { Intragenesis }\end{array}$ & Low & Yes & Yes & $\begin{array}{c}\text { Easy with } \\
\text { Information }\end{array}$ & Possible \\
\hline & Reverse Breeding & $\mathrm{N} / \mathrm{A}$ & Yes & No & $\mathrm{N} / \mathrm{A}$ & N/A \\
\hline & Agro-infiltration & $\mathrm{N} / \mathrm{A}$ & N/A & N/A & $\mathrm{N} / \mathrm{A}$ & N/A \\
\hline & Grafting & $\mathrm{N} / \mathrm{A}$ & $\mathrm{N} / \mathrm{A}$ & N/A & N/A & N/A \\
\hline & RdDM & $\mathrm{N} / \mathrm{A}$ & Yes & No & $\mathrm{N} / \mathrm{A}$ & $\mathrm{N} / \mathrm{A}$ \\
\hline
\end{tabular}

$\mathrm{DNA}$ 의 존재 여부가 다르다. 먼저 $\mathrm{SDN}-1,2$ 의 산물 내에는 외 래 DNA가 없으나 SDN-3에서는 외래 DNA가 도입된다. 자체 의 유전물질만을 이용하는 cisgenesis는 기술의 발전에 따라 외 래 DNA를 이용하지 않을 수 있어 외래 DNA의 존재를 배제 할 수 있으나, intragenesis는 유전자 가공 과정에서 외래 DNA 의 이용이 가능하며 경우에 따라 외래 DNA가 있을 수 있다. 역육종과 $\mathrm{RdDM}$ 은 중간단계에서 일시적으로 외래 $\mathrm{DNA}$ 를 도 입하고 후대 선발과정에서 제거하거나 중간단계에서 외래 DNA 의 사용을 배제할 수 있다. 마지막으로 $\mathrm{ODM}$, 아그로접종, 접 목 등의 기술이 적용된 산물에는 외래 DNA가 없다.

변이의 검출과 동정은 대상 생물 종의 유전체에 어떤 변이가 일어났는지 그리고 그 변이가 어떻게 일어났는지를 확정하는 것 이다. 여기에는 주로 단백질과 DNA 분석이 활용된다. 단백질 분석에 있어서는 항체-항원 반응 메카니즘을 이용하여 변이체 가 생산하는 단백질과 특이적으로 반응하는 항체를 이용해서 검 색키트, 웨스턴 분석 등의 기술을 활용한다. DNA 분석에는 유 전체 염기서열 전체의 분석(whole genome sequencing), 타겟 단편의 분석(PCR) 혹은 변이와 연관된 마커 분석 기술 등이 널 리 이용된다. 전통육종 산물은 일반적으로 마커나 유전체서열 분석을 통해 검출이 가능하지만, 단백질과 DNA 서열 분석으로 대상 생물체에 발생한 변이 모두를 검출하는 것은 불가능하다. 또한 다른 기술과 달리 전통 육종 산물은 형질도입과 관련된 정보를 확보하기 어려워 분석 결과의 불확실성이 매우 크다고 할 수 있다. $\mathrm{GM}$ 기술의 경우 개발에 활용된 유전자 정보(DNA 서열, 단백질 서열, 구조 등)가 확보되어 있으므로 검출과 동정 이 가능하며, 도입 유전자의 삽입위치 동정 등을 통해 비의도 적 변이의 발생을 예측할 수 있다. 신육종 기술에 있어서는 변
이와 관련된 정보가 있을 경우 검출이 가능하지만, 정보가 없 을 경우에는 전통육종에 의한 변이 발생과 구별할 수 없는 경 우가 있다. 즉 전통육종 산물과 매우 유사한 ODM, SDN-1, 2 산물은 변이발생 위치 정보를 활용할 경우 검출이 상대적으로 용이하지만 최종산물을 전통육종과 구별하는 것은 불가능하다. $\mathrm{SDN}-3$, cisgenesis, intragenesis의 경우 검출과 동정 가능성은 형질전환과 동일하다. 마지막으로 역육종, 아그로접종, 접목, $\mathrm{RdDM}$ 은 대상 생물 유전체의 유전자변형을 유도하는 기술이 아 니므로 변이 발생 검출과 동정의 대상이 아니다.

\section{각 국의 신육종기술 규제 정책 동향}

앞에서도 지적한 바와 같이 신육종기술의 규제 체계는 아직 확 립되지 못한 실정이다. 그러나 미국 등 일부 국가에서는 신육 종기술 중 유전자교정의 규제와 관련된 정책을 결정하였거나 정 책 결정이 가시화되고 있다. 이 장에서는 각 국의 사례를 통해 유전자교정 규제와 관련된 현황을 기술하였다.

\section{미국}

미국은 세계 각 국 중 유전자 교정에 대한 정책적 입장을 가장 명확하게 밝힌 국가이다. 2012년 ZFN 기술로 육성한 옥수수에 대해 규제하지 않는다는 결정을 내린 후, 2015년부터 2018년 10월까지 “7 CFR part 340”의 ‘Am I regulated?' 컨설팅 프로 그램을 거쳐 규제가 면제된 케이스가 26건에 이르며[27], 2018 년 4월 미국 농무성은 유전자교정으로 육성한 작물은 더 이상 규제하지 않을 것이라고 발표하였다. 발표에 따르면 유전자가 
제거되거나 내재 유전자가 더해지는 경우에는 규제 대상이 아 니다[14].

\section{캐나다}

캐나다는 대표적인 산물 중심의 규제 국가로서 방법에 상관 없 이 새로운 형질을 보이는 작물은 규제 대상으로 삼는다. 유전 자교정 산물도 기존 정책에 따라 적용 기술이 아니라 산물의 신규 형질 여부가 규제 여부를 결정하는 요인이다[46].

\section{아르헨티나와 남미}

대부분의 남미국가들은 카르타헤나 바이오안전성 의정서에 따 라 자국의 규제체계를 확립하였다. 아르헨티나의 경우 바이오안 전성 의정서의 당사국은 아니지만 자국의 법(Resolution no. $701 / 2011)$ 에서 $\mathrm{GMO}$ 를 바이오안전성 의정서의 정의와 동일하게 규정했다. 유전자교정과 관련된 아르헨티나의 입장은 Resolution no.173/2015에 잘 나타나 있는데, $\mathrm{GMO}$ 로서의 규제 여부는 case-by-case 분석을 통해 결정하며 transgene이 없을 경우에는 규제대상에서 제외한다[47,48]. 칠레와 브라질 그리고 콜롬비아 는 아르헨티나의 정책적 결정을 따라가는 추세로 칠레는 2017 년, 브라질은 2018년 1월에 transgene이 없으면 규제하지 않을 것임을 발표했다. 최근에는 콜롬비아 정부가 유전자교정으로 육 성한 카카오를 규제하지 않을 것이라고 발표했다[49].

\section{유럽연합}

유전자교정과 관련된 유럽연합의 정책 결정은 일정 부분 혼란 상태에 빠진 것으로 보인다. GMO 규제를 엄격하게 시행하고 있는 유럽연합은 2006년 네델란드 유전자변형위원회(Commission on Genetic Modification) [3], 2011년 유럽연합집행위원회 공동 연구센터(European Commissions Joint Research Center) [5], 2017년 EC 과학자문단(EC SAM; Science Advice Mechanism) [7] 등에서 신육종기술의 특성을 검토한 후 transgene이 없는 신육 종기술 산물은 규제 대상에서 제외할 것을 제안하는 등 전향적 정책 결정의 가능성을 보였다. 그러나 2018년 7월25일 유럽사 법재판소에서 비자연적으로 발생하는 모든 변이체는 규제 대상 이며, 단 방사능 변이와 같이 오랜 기간 동안 익숙한 것은 규 제에서 예외를 둔다고 판결함으로써 향후 유럽연합 집행위의 후 속조치에 관심이 쏠리고 있다[15]. 앞으로 예상되는 유럽연합 집행위의 후속조치 시나리오로는 사법재판소의 평결을 수용하 여 유전자교정 산물을 $\mathrm{GMO}$ 의 범주에서 규제하거나 $\mathrm{GMO}$ 규 제 규정(Directive 2001/18/EC) 중 규제 예외를 기술한 Annex $1 \mathrm{~B}$ 를 개정하여 유전자교정 산물의 일부(예를 들어 $\mathrm{SDN}-1,2$ ) 를 규제 예외 대상으로 삼거나 $\mathrm{GMO}$ 규제 체계의 전면적 개편 을 예상할 수 있다[50]. 한편 $\mathrm{EU}$ 체제에서 벗어나려는 영국의 BREXIT가 끝난 후 영국의 유전자교정 규제와 관련된 입장은 역내의 규제 흐름에 큰 영향을 미칠 것으로 보이며, 현 시점에 서는 영국이 BREXIT 후 규제에 대해 유연한 입장을 취할 것 으로 예상된다[51].

\section{뉴질랜드와 호주}

뉴질랜드 환경보호 당국은 2014년 유전자교정 산물을 GMO 규 제에서 제외한다고 결정하였지만 법원 판결에 의해 이 결정이 번복됐다. 이에 따라 뉴질랜드는 2016년부터 SDN-1까지도
$\mathrm{GMO}$ 로 규제하고 있다[52]. 호주는 아직 정책적으로 최종 결정 을 내리지는 않았지만 신육종기술의 특성이 전통 육종에 가까 울 경우(SDN-1 등) 규제를 하지 않고 $\mathrm{SDN}-3$ 와 같이 형질전환 에 가까울수록 규제를 한다는 입장인 것으로 알려졌다[53].

\section{중국}

중국도 아직 유전자교정 규제 정책을 확립하지 않은 상태다. 다 만 최근 월스트리트 저널 보도에 따르면, 중국 정부는 이 기술 과 관련된 기술 경쟁력 확보에 관심이 많으며 관련 규제도 전 향적인 입장을 취할 것으로 전망하고 있다[54].

\section{이스라엘}

이스라엘의 National Committee for Transgenic Plants는 2016 년 유전자교정 산물도 Seed Act의 정의와 가이드라인에 따라 규제하기로 결정하였다. 여기에 따르면 식물 유전체에 외래 DNA가 들어가지 않았으면 규제 대상이 아니다[55].

\section{일본}

2018년 일본 환경성은 유전자교정 기술로 만든 생물의 규제에 대한 정책안을 결정하고 이에 대한 공개의견 수렴 절차를 완료 하였다. 이 정책안의 요지는 SDN-1은 규제대상이 아니고, SDN2와 3은 규제 범위에 포함하되 self-cloning 및 natural occurrence 는 규제 대상에서 제외하는 일본의 기존 Living Modified Organism $(\mathrm{LMO})$ 정책을 유전자교정에도 적용하겠다는 것이다. 여기에서 self-cloning이란 숙주와 동일한 분류학적 종에 속하는 생물의 핵산만을 도입하는 것이며, natural occurrence는 숙주가 속한 종과 자연조건에서 핵산을 교환하는 종에 속하는 생물의 핵산을 도입하는 것을 말한다[56].

\section{기타 국가}

말레이시아는 아직 신육종기술의 산물에 대한 정책을 결정하지 는 않았다. 그러나 역육종과 $\mathrm{RdDM}$ 등을 제외한 cisgenesis, intragenesis, 합성생물학, 접목의 경우 $\mathrm{GMO}$ 로 규제할 가능성이 높을 것으로 예상되며, 유전자교정과 일시 발현 기술의 규제에 대해서는 아직 예상하기 어렵다[57]. 인도의 경우 1989년에 제 정된 법률에서 정의한 'gene technology와 genetic engineering' 에 따라 규제 여부를 결정할 예정이며 현재는 적절한 가이드라 인과 표준 집행 규범을 준비 중이다[58].

\section{각 국의 GMO 규제 체계와 신육종기술 규제 전망}

2018년 11월 현재 EU를 비롯한 세계 171개국이 가입한 카르타 헤나 바이오안전성의정서(CPB, Cartagen Protocol on Biosafety) 는 유전자변형생물체 $(\mathrm{LMO})$ 의 국가간 이동을 규제하는 국제협 약이다. 또한 의정서는 그 이행을 위해 당사국들이 구축했거나 구축 중인 법률과 아르헨티나 등 일부 비당사국의 GMO 규제 를 위한 법률 제정의 기반이 되었다. 따라서 신육종기술 규제 여부와 관련된 각 국의 $\mathrm{GMO}$ 규제 체계를 이해하기 위해서는 우선 $\mathrm{CPB}$ 를 살펴볼 필요가 있다[59]. $\mathrm{CPB}$ 는 제 3 조 $(\mathrm{g})$ 항에서 규제 대상이 되는 $\mathrm{LMO}$ 를 '현대생명공학을 이용하여 얻어진 새 로운 조합의 유전 물질을 가진 살아있는 생물체'로 정의하고 있 
으며 (i)항에서는 현대생명공학을 재조합 DNA나 세포 혹은 세 포 내 소기관에 핵산을 직접 주입하는 것을 포함한 생물체에 핵산 기술을 적용하는 것으로 정의하고 있다. 즉 $\mathrm{CPB}$ 는 현대 생명공학기술(process)을 이용해서 만든 생물체 중 새로운 조합 의 유전물질을 가진 것(product)을 $\mathrm{LMO}$ 규제 대상으로 삼았다. 이 규정에 대해 Atanassova와 Keiper는 현대생명공학기술 이용 이라는 점을 들어 과정 중심(process based)의 규제라고 했다[8]. 반면에 Ishii와 Araki는 새로운 조합의 유전물질을 가진 생물체 가 규제 대상임을 들어 산물 중심(product based) 규제라는 결 론을 내린 바 있다[60].

세계 각 국의 $\mathrm{LMO}$ 규제 중에서 완전한 산물 중심 규제 체 계를 갖춘 나라는 캐나다라고 할 수 있다. 캐나다의 경우 '새 로운 형질(novel trait)를 가진 작물'은 모두 규제대상으로 삼는 다. 미국도 이와 유사하게 식물해충과 잡초, 건강에 해로운 독 성 물질을 포함하는 식품과 환경에 비합리적일 정도로 악영향 을 끼치는 살충제 등을 규제 대상에 포함시켰다. 즉 적용된 기 술에 상관없이 산물의 형질을 규제 결정에 있어 가장 중요한 요인으로 삼았다. 반면에 산물의 성질에 상관 없이 적용기술만 을 대상으로 규제하는 완전한 과정 중심 규제 국가는 없다고 할 수 있다. Table 2에서는 Ishii와 Arakirk가 조사한 34개국 중 30 개국을 대상으로 카르타헤나 관련법에 명문화된 $\mathrm{GMO}$ 정 의를 분석했다[60]. 표에 따르면 30개국을 방법에 상관없이 산 물의 성질에 따라 규제하는 캐나다와 미국 2 개국(그룹 1 ), '비 자연적 방법'으로 '유전적 변이'를 일으킨 생명체로 정의한 국 가는 $\mathrm{EU}$ 를 비롯한 8 개국(그룹 2), '현대생명공학 혹은 유전공 학’을 이용해 ‘유전적 변이’가 일어난 생명체로 정의한 국가는 호주를 비롯한 8개국(그룹 3), 마지막으로 '현대생명공학/유전 공학' 기법으로 ‘새로 조합된 유전물질'을 포함하게 된 생물체 로 정의한 국가가 아르헨티나 등 10 개국(그룹 4)로 분류할 수 있다. 각 그룹간의 차이는 규제 대상인 기술과 산물의 범위를 넓게 잡느냐 혹은 좁게 설정하느냐인 것으로 보인다. 즉 전형 적인 산물 중심 규제 국가인 캐나다와 미국의 경우(그룹 1) 적 용 기술을 제한하지 않고 있으며 과정 중심 규제의 특성을 뚜 렷하게 보이는 유럽연합 등(그룹 2)은 다른 그룹에 비해 규제 대상인 적용 기술과 산물의 범위를 상대적으로 넓게 설정했다. 한편 그룹 3에 속하는 국가들은 그룹 2에 비해 규제 대상 기 술의 범위를 제한하고 있으며 그룹 4 의 경우 그룹 2 에 비해서
는 규제 대상 기술의 범위를, 그룹 3 에 비해서는 산물의 범위 를 제한하고 있다.

Ishii와 Araki의 분석에 따르면 과정 혹은 산물 중심 등 $\mathrm{GMO}$ 규제범위의 차이는 $\mathrm{GMO}$ 의 재배와 활용에 영향을 미치지 않는 다[60]. 그러나 Table 2에서 정리한 각 국의 GMO 규제 범위와 위에서 기술한 유전자교정 규제 정책이 가시화된 사례를 비교 해보면, 그룹 2에 속하는 유럽연합과 뉴질랜드를 제외한 그룹 1 의 캐나다와 미국, 그룹 3 의 호주와 브라질, 그리고 그룹 4 의 아르헨티나, 콜롬비아, 일본, 중국 등은 신육종기술, 특히 유전 자교정 기술에 대해 전향적 입장을 취하고 있으며 최소한 SDN1에 대해서는 규제 대상에서 제외했거나 제외할 것이 예상된다.

Ishii와 Araki의 분석에 따르면 대한민국도 일본 등과 같이 산 물 중심의 $\mathrm{GMO}$ 규제체계를 갖추고 있다[60]. 또한 Table 2의 분석 결과에 따르면 대한민국은 규제 대상 기술과 산물의 범위 를 좁게 설정한 그룹 4에 속한다. 현재 대한민국에서는 민간 차 원에서 신육종기술에 대한 규제 가능성 혹은 타당성에 대해 논 의를 진행하고 있으며, 정부에서도 이 문제에 대해 다각적인 검 토를 하고 있을 것으로 추측된다. 앞에서 기술한 바와 같이 대 한민국과 같은 그룹에 속한 국가들 다수가 유전자교정 기술이 적용된 $\mathrm{SDN}-1$ 을 규제 대상 밖에 두는 정책을 취한다는 국외 동향은 앞으로 정부의 정책 결정에 참고할만한 가치를 가진다 고 할 수 있다.

국내의 신육종기술의 규제 여부와 관련해서 검토해야하는 또 하나의 과제는 $\mathrm{GMO}$ 규제와 관련이 있는 국내법 간의 관계이 다. 현재 국내에는 카르타헤나 바이오안전성의정서 이행을 위한 ‘유전자변형 생물체 국가간 이동 등에 관한 법(LMO법)' 이외 에도 '식품위생법'과 ‘농수산물품질관리법' 등이 GMO 표시제 와 유전자변형 식품의 안전성 심사에 대한 규정을 담고 있다 [61-63]. LMO법에서는 $\mathrm{LMO}$ 를 "인위적으로 유전자를 재조합하 거나 유전자를 구성하는 핵산을 세포 또는 세포 내 소기관으로 직접 주입하는 기술(현대생명공학기술)을 이용하여 새롭게 조합 된 유전물질을 포함하는 생물체"로 정의하고 있다. 그러나 식품 위생법에서는 유전자변형식품 등을 “현대생명공학기술을 활용 하여 재배-육성된 농산물-축산물 - 수산물 등을 원재료로 하 여 제조·가공한 식품 또는 식품첨가물"로 정의하여, 산물의 특 성 혹은 성질에 대한 규정 없이 현대생명공학 기술로 재배 육 성된 산물을 규제하도록 하였다. 이 규정을 Table 2에 따라 분

Table 2 Classification of countries or jurisdictions based on the definition of GMO described in Laws related to Cartagena Protocol on Biosafety in terms of the characteristics of process and product. Reorganized from the supplement Table 1 of reference [60]

\begin{tabular}{|c|c|c|c|c|c|c|}
\hline & & & \multicolumn{4}{|c|}{ Product } \\
\hline & & & Wide & & & Narrow \\
\hline & & & No Limit & Mutation & Novel Combination of Genetic Material & Product Properties \\
\hline \multirow{3}{*}{ Process } & Wide & No Limits & & & & $\begin{array}{c}\text { (Group 1) Canada, } \\
\text { USA (2) }\end{array}$ \\
\hline & & unnatural way & & $\begin{array}{l}\text { (Group 2) Burkina Faso, Czech Rep., } \\
\text { EU, New Zealand, Portugal, Romania, } \\
\text { South Africa, Spain, UK (9) }\end{array}$ & & \\
\hline & Narrow & $\begin{array}{l}\text { Modern } \\
\text { Biotechnology } \\
\text { or genetic } \\
\text { engineering }\end{array}$ & & $\begin{array}{c}\text { (Group 3) Australia, Bolivia, Brazil, } \\
\text { China, Honduras, India, Pakistan, } \\
\text { Slovakia (8) }\end{array}$ & $\begin{array}{c}\text { (Group 4) Argentina, Bangladesh, } \\
\text { Colombia, Costa Rica, Japan, Mexico, } \\
\text { Philippines, Korea, Russia Fed., Sudan, } \\
\text { Uruguay (11) }\end{array}$ & \\
\hline
\end{tabular}


석하면 식품위생법은 거의 완전한 과정 중심의 규제체계라고 할 수 있다. 한편 농수산물 품질관리법에서는 유전자변형농수산물 을 '인공적으로 유전자를 분리하거나 재조합하여 의도한 특성 을 갖도록 한 농수산물'로 정의하고 있으나, 이 법은 농수산물 의 표시와 관련된 규제를 규정한 법으로서 안전성 평가, 심사, 승인 등의 규제 관리와 직접적인 관련은 없다. 이와 같이 우리 나라의 유전자변형 생물체 규제관련 법 3종에 기술된 유전자변 형의 정의는 각기 다르다. 특히 안전성 심사, 승인 등의 규제 관리와 직접적인 관련이 있는 $\mathrm{LMO}$ 법과 식품위생법에서 기술 한 유전자변형 생물체 혹은 식품의 정의에 따른 규제 방향이 산물 중심(LMO법)과 과정 중심(식품위생법)으로 나뉘어 있어 이러한 부분에 대한 논의도 이루어져서 유전자교정을 비롯한 신 육종기술에 대한 규제 여부를 결정하기 전에 국내 법률간의 여 러 가능성을 미리 검토하여 규제 체계를 재정비할 필요가 있다.

\section{결 론}

국제 사회에서 그리고 각 국가별로 $\mathrm{GMO}$ 를 규제하는 것은 현 대생명공학 기술의 현재 및 잠재적 위해 가능성을 검토하여 기 술의 안전한 사용을 보장하기 위함이다. 지난 20 여년에 걸친 산 업적 활용 경험에 비춰볼 때 $\mathrm{GMO}$ 가 인간과 환경에 위협적인 존재인 지에 대해서는 의문이지만, 현존하는 법률적, 제도적 규 제 장치에 따라 매우 엄격하게 관리되어왔다. 이에 따라 $\mathrm{GMO}$ 개발과 상업화에는 필요 이상의 막대한 개발 및 규제 비용이 소요되었고, 이는 시장 진입장벽의 확대와 시장 집중화로 연결 되어 소수의 다국적 거대기업만이 기술 혁신의 과실을 따먹는 결과로 이어진 것도 부정할 수 없는 사실이다.

특정 기술의 위해성에 대해 일반화하여 기술하는 것은 불가 능하다. 신기술의 위해성에는 제품의 특성(생리 대사, 생화학적 형질특성 등)뿐만 아니라 재배 중 환경의 변화, 영농방식 등 다 양한 요인이 영향을 미치므로 일반화하여 비교할 수 없다. 다 만 의도하지 않은 위해성은 변이의 무작위성에 의해 발생할 가 능성이 높다는 점을 고려하면 각 기술의 비의도적, 무작위적 변 이 창출 가능성을 비교하여 위험가능성을 간접적으로 비교할 수 는 있을 것이다.

이 보고에서 우리는 신육종기술로 분류되는 작물의 새로운 변이 창출에 대해 검토했다. 이들 중 일부는 최종 산물 내에 새 롭게 조합된 유전물질을 포함(cisgenesis, intragenesis, SDN-3 등)하며 나머지는 신작물 육성 중간단계에서는 포함하지만 최 종적으로 제거(역육종, $\mathrm{RdDM}, \mathrm{SDN}-1, \mathrm{SDN}-2$ )하거나 새롭게 조합된 유전물질의 도입(transgenesis)과정을 거치지 않는다(접목, 아그로 접종, $\mathrm{ODM}, \mathrm{SDN}-1, \mathrm{SDN}-2)$. 따라서 신육종기술 중 $\mathrm{LMO}$ 법과 관련해서 규제 타당성 여부를 검토해야 할 기술로는 최종적으로 새롭게 조합된 유전물질을 가지고 있는 cisgenesis, intragenesis, SDN-3와 중간단계에서 transgenesis를 거치는 역육 종, $\mathrm{RdDM}, \mathrm{SDN}-1, \mathrm{SDN}-2$ 를 들 수 있다. 위에서의 비교 검토 한 바에 따르면 신육종기술이 적용된 육종 산물은 모두 전통육 종과 $\mathrm{GM}$ 기술에 비해 무작위적 변이발생 가능성이 낮으며, 비 의도적 변이 발생의 가능성도 낮다고 할 수 있다. 또한 SDN-1 과 -2 의 경우 창출된 변이가 기술 특성상 방사능 혹은 화학물 질 처리에 의한 변이 창출과 변이 위치를 정확하게 조절할 수
있다는 점을 제외하곤 동일하다는 점에서 산물의 차별화는 불 가능하다.

유전자교정과 관련된 국제 동향을 분석한 결과 산물 중심의 경향을 보이는 $\mathrm{GMO}$ 규제 체계를 채택한 국가들은 외래 유전 자(transgene)가 없는 경우 $\mathrm{GMO}$ 규제에 포함시키지 않는 경향 을 보였다. 한편 과정 중심의 규제 국가인 뉴질랜드와 유럽연 합은 SDN-1을 규제 대상에서 제외하려는 움직임을 보이다가 사법기관의 제동이 걸린 사례라고 할 수 있다. 사법기관의 유 일한 판단 기준이 기술 간의 실질적 차이가 아닌 관련법에 기 술된 규제 대상이라는 점에서 실제로 정책을 수립하고 시행하 는 부서와는 입장이 다르다는 것이 이러한 결과로 이어졌다고 생각된다.

우리나라의 경우 유전자변형 작물 혹은 농산물을 규제하는 양대 축인 $\mathrm{LMO}$ 법과 식품위생법이 서로 다른 규제 개념을 가 지고 있어 유전자교정 등 신기술의 규제여부를 결정하는데 논 의가 필요하다.

지난 20 여년간 우리는 유전자변형 작물의 규제체계를 운영하 면서 적지 않은 시행 착오와 경험을 쌓았다. 신육종기술을 어 떠한 방식으로 규제, 관리할 지를 결정하고 이에 걸맞은 규제 체계를 구축함에 있어서 기술 산물의 불확실성, 실질적 위해가 능성, 규제 정책 집행 가능성 및 규제로 인해 얻을 수 있는 이 익과 문제점 등을 면밀하게 검토해야 한다. 이러한 과정에서 그 동안 유전자변형 작물을 대상으로 집행했던 규제 정책의 경험, 도출됐던 문제점 등도 함께 고찰해서 합리적인 정책 결정을 할 필요가 있다.

감사의 글 본 연구는 농촌진흥청 차세대바이오그린21사업(과제번호 PJ013923) 연구비를 지원받았으며, 이에 감사드립니다.

\section{References}

1. ISAAA (2017) Global status of commercialized biotech/GM crops in 2017: Biotech crop adoption surges as economic benefits accumulate in 22 years. ISAAA Brief No. 53. ISAAA, Ithaca

2. Schurman L (2004) Fighting "frankenfoods": Industry opportunity structures and the efficacy of the anti-biotech movement in western Europe. Social Problems 51: 243-268

3. COGEM (2006) New techniques in plant biotechnology, COGEM report CGM/061024-02

4. European Commission (2008) Working group on the establishment of a list of techniques falling under the scope of directive 2001/18/EC on the deliberate release of genetically modified organisms into the environment and directive 90/219/EEC on the contained use of genetically modified micro-organisms. ENV B3/AA/D

5. Lusser M, Parisi C, Plan D, Rodriguez-Cerezo E (2011) New plant breeding techniques: state-of-the-art and prospects for commercial development. EC JRC Reference Report EUR 24760 EN

6. Lusser M, Parisi C, Plan D, Rodriguez-Cerezo E (2012) Deployment of new biotechnologies in plant breeding. Nat Biotech 30: 231-239

7. European Commission (2017) New techniques in agricultural biotechnology. Scientific Advisory Mechanism, High Level Group of Scientific Advisors. Explanatory Note 02/2017

8. Atanassova A, Keiper F (2018) Plant breeding innovation: A global perspective. Cereal Chem 95: 8-16

9. Schaart JG, van de Wiel CCM, Lotz LAP, Smulders MJM (2016) Opportunities for products of new plant breeding techniques. Trends 
Plant Sci 21: 438-449

10. CBGP UPM-INIA (2018) Regulating genome edited organisms as GMOs has negative consequences for agriculture, society and economy http://www.cbgp.upm.es/files/Position_paper_on_the_ECJ_ruling_on CRISPR22_Oct_2018_CONFIDENTIAL.pdf

11. Steinbrecher RA (2015) Genetic engineering in plants and the "new breeding techniques (NBTs)", Inherent risks and the need to regulate. EcoNexus Briefing December 2015. http//nuffieldbioethics.org/wpcontent/uploads/genome-editing-evidence-EcoNexus.pdf. Accessed 30 October 2018

12. Koh HJ (2018) Management measures of plant varieties by the application of genome editing techniques. Proceedings of Joint Symposium on Genome Editing, Kosid and Kor Soc Breeding Sci 71-96

13. Nuijten E, Messmer MM, Lammerts van Bueren ET (2017) Concepts and strategies of organic plant breeding in light of novel breeding techniques. Sustainability 9: 18

14. USDA (2018) Secretary Perdue issues USDA statement on plant breeding innovation. Press Release No $0070.18 \mathrm{https} / / / \mathrm{www} . u s d a . g o v /$ media/press-releases/2018/03/28/secretary-perdue-issues-usda-statementplant-breeding-innovation

15. Court of Justice of the European Union (2018) Organisms obtained by mutagenesis are GMOs and are, in principle, subject to the obligations laid down by the GMO Directive. Press Release No 111/18 https://curia. europa.eu/jcms/upload/docs/application/pdf/2018-07/cp180111en.pdf

16. Wight AJ (2018) Strict EU ruling on gene-edited crops squeezes science. Nature 563: 15-16

17. Lassoued R, Smyth SJ, Phillips PWB, Hesseln (2018) Regulatory uncertainty around new breeding techniques. Frontiers in Plant Sci 9: 110

18. Kim JY (2018) Recent progress in CRISPR-based genome editing techniques and domestic research status. Proceedings of Joint Symposium on Genome Editing, Kosid and Kor Soc Breeding Sci 31-54

19. Kim YG, Cha J, Chandrasegaran S (1996) Hybrid restriction enzymes: zinc finger fusions to FokI cleavage domain. Proc Natl Acad Sci USA 93: $1156-1160$

20. Carrol D (2011) Genome engineering with zinc-finger nucleases. Genetics 188: 773-782

21. Gaj T, Gerbach Ca, Barbas III CF (2013) ZFN, TALEN and CRISPR Cas-based methods for genome engineering. Trends Biotechnol 31: 397405

22. Kamburova VS, Nikitina EV, Shermatov SE, Buriev ZT, Kumpatla SP, Emani C, Abdurakhmonov I (2017) Genome editing in plants: An overview of tools and application. Int'l J Agronomy https://doi.org/ $10.1155 / 2017 / 7315351$

23. Gupta RM, Musunuru K (2017) Expanding the genetic editing tool kit: ZFNs, TALENs and CRISPR-Cas9. J Clin Invest 124: 4154-4161

24. Malzahn A, Lowder L, Qi Y (2017) Plant genome editing with TALEN and CRISPR. Cell Biosci DOI 10.1186/s13578-017-0148-4

25. Haft DH, Selengut J, Mongodin EF, Nelson KE (2014) Aguild of 45 CRISPR-associated (Cas) protein families and multiple CRISPR/Cas subtypes exist in prokaryotic genomes. PLoS Comput Biol 1: 474-483

26. Perkin IC, Adrianos SI, Oppert B (2016) Gene disruption technologies have the potential to transform stored product insect pest control. Insects 7: 46 doi:10.3390/insects7030046

27. USDA APHIS (2018) Regulated article letters of inquiry https:// www.aphis.usda.gov/aphis/ourfocus/biotechnology/am-i-regulated/ Regulated_Article_Letters_of Inquiry

28. Clasen BM, Stoddard TJ, Luo S, Demorest ZL, Li J, Cedrone F, Tibebu R, Davison S, Ray EE, Daulhac A, Coffman A, Yabandith A, Retterath A, Haun W, Baltes NJ, Mathis L, Voytas DF, Zhang F (2016) Improving cold storage and processing traits in potato through targeted gene knockout. Plant Biotech J 14: 169-176

29. Demorest Z, Coffman A, Baltes NJ, Stoddard TJ, Clasen BM, Luo S, Retterath A, Yabandith A, Gamo ME, Bissen J, Mathis L, Voytas DF, Zhang F (2016) Direct stacking of sequence-specific nuclease-induced mutations to produce high oleic and low linolenic soybean oil. BMC Plant Biol 16:225 DOI 10.1186/s12870-016-0906-1

30. Bomgardner MM (2017) CRISPR: A new toolbox for better crops. Chemical and Engineerin News 95: 30-34

31. Hall SS (2016) Editing the mushroom. Scientific America https://www. aaas.org/sites/default/files/Stephan\%20Hall\%20-Gene-EditedMushroom $\% 20($ SciAm $\% 20(3)$.pdf

32. Wang Y, Cheng X, Shan Q, Zhang Y, Liu J, Gao C, Qui YL (2014) Simultaneous editing of three homeoalleles in hexaploid bread wheat confers heritable resistance to powdery mildew. Nature Biotech 32: 947951

33. Petolino JF (2015) Genome editing in plants via designed zinc finger nucleases. In Vitro Cell Dev Biol 51: 1-8

34. Sauer NJ, Mozoruk J, Miller RB, Warburg ZJ, Walker KA, Beetham PR, Schöpke CR, Gocal GFW (2016) Oligonucleotide-directed mutagenesis for precision gene editing. Plant Biotech J 2016 14: 496-502

35. Espinoza c, Schlechter R, Herrera D, Torres E, Serrano A, Medina C, Arce-Johnson P (2013) Cisgenesis and intragenesis: New tools for improving crops. Biol Res 46: 323-331

36. Jo K-W, Kim C-J, Kim S-J, Kim T-Y, Bergervoet M, Jongsma MA, Visser RGF, Jacobsen E, Vossen JH (2014) Development of late blight resistant potatoes by cisgene stacking. BMC Biotech 14: 50

37. Kost TD, Gessler C, Jänsch M, Flachowsky H, Patocchi A, Broggini GAL (2015) Development of the first cisgenic apple with increased resistance to fire blight. PLoS ONE 10: e0143980. doi:10.1371/ journal.pone. 0143980

38. Schaart JG, Kjellsen TD, Mehli L, Heggem R, Iversen T-H, Schouten HJ, Krens FA (2011) Towards the production of genetically modified strawberries which are acceptable to consumers. Genes, Genomes \& Genomics 5: 102-107

39. EPSO (2016) Reverse breeding. Meet the parent. Crop Genetic Improvement Techniques Fact Sheet http://www.epsoweb.org/file/2183

40. Kumari P, Nilanjaya, Singh NK (2018) Reverse breeding: Accelerating innovation in plant breeding. J Pharmacognosy Phytochem SP1: 18111813

41. Dirks R, van Dun K, de Snoo CB, van den Berg M, Lelivelt CLC, Voermans W, Woudenberg L, de Wit JPC, Reinink K, Schut JW, van der Zeeuw E, Vogelaar A, Freymark G, Gutterling EW, Keppel MN, van Drongelen P, Kieny M, ELLUL P, Touraev A, Ma H, de Jong H, Wijnker E (2009) Reverse breeding: a novel breeding approach based on engineered meiosis. Plant Biotech J 7: 837-845

42. Lee RWH, Strommer J, Hodgins D, Shewen PE, Niu YQ, Lo RYC (2001) Towards development of an edible vaccine against bovine pneumonic pasteurellosis using transgenic white clover expressing a Mannheimia haemolytica A1 leukotoxin 50 fusion protein. Infection and Immunity 69: 5786-5793

43. Lusser M, Davies HV (2013) Comparative regulatory approaches for groups of new plant breeding techniques. News Biotech 30: 437-446

44. Goldschmidt EE (2014) Plant grafting: new mechanisms, evolutionary implication. Frontiers in Plant Sci. doi: 10.3389/fpls.2014.00727

45. Liu Z-W, Zhou J-X, Huang H-W, Li Y-Q, Shao C-R, Li L, Cai T, Chen S, He X-J (2016) Two components of the RNA-directed DNA methylation pathway associated with MORC6 and silence loci targeted by MORC6 in Arabidopsis. PLoS Genet 12: e1006026. doi:10.1371/ journal.pgen.1006026

46. Smyth SJ (2017) Canadian regulatory perspectives on genome engineered crops. GM Crops \& Food 8:35-41

47. SAGP (2015) Secretaria de agricultura ganaderia Y pesca, resolution 173/2015 https://boletinoficial.gob.ar/\#!DetalleNotmativa/1095531/null

48. Whelen AI, Lema MA (2015) Regulatory framework for gene editing and other new breeding techniques (NBTs) in Argentina. GM Crops \& Food 6: 253-265

49. Schmidt S (2018) To regulate or not to regulate: Current legal status for gene-edited crops. http://www.global-engage.com/agricultural-biotechnology/ to-regulate-or-not-to-regulate-current-legal-status-for-gene-edited-crops/ 
50. Kahrmann J (2018) Regulation of genome editing in Europe and Germany. Proceedings of Second Asia Forum on Genome Editing, Korean Biosafety Clearing House, 59-71

51. UK (2018) Evidence check: GM and gene editing-Government statement. https://www.parliament.uk/documents/commons-committees/ science-technology/evidence-tests/GM-and-Gene-Editing.pdf.

52. Fritsche S, Poovaiah C, MacRae E, Thoriby G (2018) A New Zealand perspective on the application and regulation of gene editing. Frontiers in Plant Sci 9: 1323. doi: 10.3389/fpls.2018.01323

53. Mitchell H (2018) Australian regulation, risk assessment and genome edited organisms. Proceedings of Second Asia Forum on Genome Editing, Korean Biosafety Clearing House, 261-276

54. Bunge J, Craymer L (2018) Scientists in China race to edit crop genes, sowing unease in US. Wall Street Journal https://www.wsj.com/articles/ scientists-in-china-race-to-edit-crop-genes-sowing-unease-in-u-s-1525611601

55. USDA FAS (2017) Israel agricultural biotechnology annual 2017. https:// gain.fas.usda.gov/Recent\%20GAIN\%20Publications/ Agricultural\%20Biotechnology\%20Annual_Tel\%20Aviv_Israel_12-12017.pdf

56. Tachikawa M (2018) Regulatory discussions and consumer perceptions on genome editing in Japan. Proceedings of Second Asia Forum on Genome Editing, Korean Biosafety Clearing House, 239-255
57. Abdullah MFF (2018) Regulatory issues on genome editing in Malaysia. Proceedings of Second Asia Forum on Genome Editing, Korean Biosafety Clearing House, 91-103

58. Rahman SJ (2018) Genome editing technologies: Existing monitoring and compliance protocols for confined field trials of GE crops in India. Proceedings of Second Asia Forum on Genome Editing, Korean Biosafety Clearing House, 131-142

59. Biosafety Clearing House (2018) Cartagena protocol on biosafety. https:/ /bch.cbd.int/protocol/

60. Ishii T, Araki M (2017) A future scenario of the global regulatory landscape regarding genome-edited crops. GM Crops \& Food 8: 44-56

61. WIPO (2014) Republic of Korea. Act on transboundary movement, etc., of living modified organisms (Act No.6448 of March 28, 2001, as amended up to Act No. 12833 of November 19, 2014). http:// www.wipo.int/wipolex/en/details.jsp?id=15643

62. KFDA (2017) Food sanitation act (Act No. 15277, December 19, 2017). https://elaw.klri.re.kr/kor_mobile/viewer.do?hseq=46429\&type=sogan\&key $=31$

63. MAFRA (2016) Agricultural and fishery products quality control act (Act No 14483, December 27, 2016). https://elaw.klri.re.kr/kor_mobile/ viewer.do?hseq $=42239 \&$ type $=$ sogan $\&$ key $=7$ 